\title{
A rendszeres reggelizés mint szokáskialakítás és értékközvetí- tés a középiskolás korosztályban
}

\author{
Regular breakfast as a knowledge and habit forming among students in sec- \\ ondary education
}

\author{
Szerzők: Lelovics Zsuzsanna $\square$ \\ Eötvös Loránd Tudományegyetem, Neveléstudományi Doktori Iskola
}

Beküldve: 2017.02.14.

doi: $10.24365 /$ ef.v58i1.140

\begin{abstract}
Összefoglaló: Az ezredfordulón a magyar tanulók körében a reggelit otthon nem fogyasztók aránya 23\%-a volt, míg kifejezetten a középiskolás korosztályban a diákok 62\%-a reggelizett. A 2016ban végzett Iskoláskorú gyermekek egészségmagatartása (Health Behaviour in School-aged Children - HBSC) felmérés során kapott eredmények szerint a hétköznapokon soha nem reggeliző fiúk aránya a 9. évfolyamon 32\%, a 11. évfolyamon 37\%, míg a lányoké a 9. évfolyamon 39\%, a 11. évfolyamon $41 \%$ volt. Szerző célul tǔzte ki a középiskolások körében a reggelizés mint táplálkozási szokás rendszeresebbé tételére irányuló törekvés eredményességének mérését, ennek érdekében a táplálkozási szokások nyomon követését, továbbá az általa vezetett beavatkozás hatékonyságának megállapítását.
\end{abstract}

Módszertan: A tíz tanórából álló oktatási folyamatban (1, illetve 2 tanév) egészséges, ismert táplálékallergiában nem szenvedő, önkéntes részvételü 9. és 10. évfolyamos (14,5-16,5 éves) tanulók ( $n=364 ; 181$ fiú /50\%/ és 183 lány /50\%/) vettek részt. További két tanévben nyomonkövetés történt. Az adatfelvétel táplálkozási kérdőív és a táplálkozási napló párhuzamos kitöltésén, az értékelés az elemzéseken túl azok összevetésén is alapult.

Eredmények: A középiskolás korosztály szinte kivétel nélkül (99\%) tisztában volt a reggeli jelentőségével az oktatás végére (kezdetekor: 85\%). Az ismeretek szokásrendszerbe történő beépítése azonban ettől az aránytól nagymértékben elmaradt: 48\%-ról - az oktatás végére (átmenetileg) $72 \%$-ra - a kutatás végére pedig 59\%-ra nőtt a rendszeresen reggeliző diákok aránya. A korábban rendszeresen reggelit nem fogyasztó diákok 21\%-a vált rendszeres reggelizővé.

Következtetések: $A$ kutatás elején és a kutatás végén sem volt szignifikáns kapcsolat $\left(\chi^{2}=0,6100\right.$ és $\left.\chi^{2}=2,7712 ; p>0,05\right)$ a tudás és a szokás között a rendszeres reggelizés vonatkozásában.

Összegzés: A diákok egészséges táplálkozásra nevelése során nagyon fontos behatárolni azt az információtartalmat, ami szükséges és elégséges az egészséges táplálkozáshoz. A rendszeres reggelizés fontossága egyértelműen ilyen ismeret. A szokások kialakítása, és a szokások megváltoztatása nem tekinthető azonos nevelési feladatnak. A rögzült szokások megváltoztatása nehezebb, hosszabb időt igénylő feladat.

Kulcsszavak: táplálkozáspedagógia, reggelizés, szokáskialakítás, középiskolások

Summary: Introduction: Around the Millennium the ratio of Hungarian students who did not have breakfast was $23 \%$, while $62 \%$ of the students in secondary education had breakfast. In 2016, the result of the Health Behaviour in School-aged Children (HBSC) study showed that the ratio of the boys in the 9th grade who are not having breakfast during weekdays was $32 \%$, and $37 \%$ in the 11 th grade, while it was $39 \%$ and $41 \%$ respectively among the girls. The author aimed to measure 
the success of the efforts put in to make regular breakfast consuming as a habit, and in order to do this, following the diet habits as well as judging the effectiveness of the launched intervention. Methods: Healthy, self-volunteered students, without known food allergy, from the 9th and 10th grade (14.5-16.5ys, $n=364 ; 181$ boys /50\%/ and 183 girls /50\%/), participated in the 10 lectures' tuition programme ( 1 or 2 academic years). The follow-up was carried out in the next two academic years. The data collection was based on diet questionnaires, diet diaries, and the evaluation was based on the analysation and comparison of the data set.

Results: Students from the secondary educational age group was almost entirely (99\%) aware of the importance of breakfast by the end of the study course (85\% at the beginning). On the other hand turning the knowledge into habit was lagging behind, the ratio of the students having regular breakfast increased from $48 \%$ to $59 \%$ by the end of the research (with a temporary increase by the end of the tuition to $72 \%$ ). $21 \%$ of those students who did not have regular breakfast earlier, became regular breakfast consumers.

Conclusions: At the beginning and by the end of the research there was no significant correlation between knowledge and habit $\left(\chi^{2}=0.6100, \chi^{2}=2.7712 ; p>0.05\right)$ concerning regular breakfast.

Summary: During the healthy diet education of students it is inevitable to define the information content that is necessary and sufficient for healthy diet. Regular breakfast is definitely such knowledge. Forming habits and changing habits are not the same educational tasks. Changing frozen habits is more difficult and requires a longer period of time to achieve.

Keywords: food pedagogy, regular breakfast, habit forming, secondary education

\section{BEVEZETÉS}

A kiegyensúlyozott, rendszeres táplálkozás része a reggeli. Az étkezések kihagyása az iskolai teljesítmény és az egészség szempontjából egyaránt kedvezőtlen. Elsősorban a reggelit kihagyó tanulókat teszi fáradékonyabbá és akadályozza meg az éhség, az energia- és tápanyaghiány a koncentrálásban és a tanulásban. A kiegyensúlyozott reggeli hozzájárul az egészséges testtömeg megőrzéséhez: a nem reggeliző gyermekek, hajlamosabbak lesznek a hízásra. ${ }^{1}$

John Locke angol filozófus és orvos 1693-ban megjelent, Some thoughts concerning Education c. müvében a betegségeket javarészt annak tulajdonította Angliában, hogy „nagyon sok húst eszünk és nagyon kevés kenyeret", s korának korszerú reggelijét akként javasolta, hogy „a gyermeknek legegészségesebb tápláléka tej, tejleves, árpakása, zabdara, főzelékek, s legajánlatosabb reggelije a jól megdagasztott és jól kisütött, vajjal megkent fekete kenyér”, vagy amikor arra int, hogy „a gyümölcsöt, melyet a gyermeknek adunk, meg kell válogatni, $\mathrm{s}$ hogy nyalánkságokra egyáltalán ne kapassuk". ${ }^{2} \mathrm{Az}$ elmúlt több mint háromszáz évben nem csak a reggeli élelmiszerei, ételei változtak nagymértékben, de annak körülményeire vonatkozó olyan - az idejükben korszerúnek számító - javaslatok is, mint például „Az étkezés ideje ne legyen minden nap szabott." Fináczy Ernő ugyanis úgy fogalmazott, hogy „Az ésszerű dietétika alapjait a gyermeknevelésre való vonatkozásában Locke az orvos rakta le." ${ }^{3}$

Hazánkban 1986-ig kellett várni az első országosan reprezentatív, serdülők körében végzett táplálkozási felmérésre. 1986-1997 között a magyar tanulók táplálkozási szokásainak egyes trendjei kedvező, mások azonban kedvezőtlen irányba mozdultak el. Ez utóbbiak közé tartozott, hogy nőtt a reggelit otthon nem fogyasztó tanulók aránya (23\%). ${ }^{4}$

\section{A „Fodor József” Országos Közegészségügyi Központ Országos Élelmezés- és Táplálkozástudományi Inté- zete (OKK-OÉTI) Táplálkozás-egészségügyi Főosztály munkatársai által 1997-től 2000-ig végzett első, rep- rezentatív komplex táplálkozás-egészségügyi felmé- rés eredményei 6347 középiskolás diák (életkor: 15-18 év) szokásain alapulnak. ${ }^{5}$ A felmérésben részt vevőkre jellemző volt a rendszertelen étkezés. A helytelen táplálkozási ritmus inkább a lányokat jel- lemezte: a fiúk 65,6\%-a; a lányok 58,6\%-a reggeli- zett naponta (összességében a diákok 62,0\%-a). ${ }^{6}$}


Németh Ágnes 2006-ban serdülőkorúak táplálkozási szokásait vizsgálta az Iskoláskorú gyermekek egészségmagatartása (HBSC), egy több mint három évtizedes múltra visszatekintő nemzetközi kutatás keretében. ${ }^{7}$ A kutatás első hivatkozott időszakában a három célcsoport a 11, a 13 és a 15 éves korosztály volt, valamint hazánkban a 17 évesek is. A 2815 fiú és 2635 lány (összesen 5450 tanuló) adatai alapján megállapítható, hogy a tanulók csaknem egyharmada a tanítási napokon sohasem reggelizett, míg a tanulók 53\%-a jelölte meg, hogy hetente legalább négyszer reggelizett hétköznapokon. A fiúk és a fiatalabbak kedvezőbb képet mutattak, mint a lányok és az idősebbek.

A hétköznapokon soha nem reggeliző fiúk aránya a 9. évfolyamon $32 \%$, a 11 . évfolyamon $37 \%$, a lányoké a 9. évfolyamon $39 \%$, a 11 . évfolyamon $41 \%$. Nem hagyható szó nélkül az a tény, hogy a 7. és a 9. évfolyamosok között e tekintetben nagy a különbség (a hétköznapokon soha nem reggeliző 7. osztályos fiúk aránya $23 \%$, a lányoké $35 \%) .{ }^{8}$

Ugyanezen kutatásnak legutóbbi, 2014. évi felmérése 2739 (9. és 11. évfolyamos) tanuló adatait elemzi. ${ }^{9}$ A 9. évfolyamon a fiúk $48 \%$-a; a lányok $35 \%$ a; a 11. évfolyamon a fiúk szintén 48\%-a, a lányok 41\%-a reggelizett minden nap. Vizsgálták külön a hétvégén - mindkét nap - reggelizőket. A 9. évfolyamon a fiúk $76 \%$-a; a lányok $71 \%$-a; a 11 . évfolyamon a fiúk $73 \%$-a; a lányok 66\%-a reggelizett szombatonként és vasárnaponként. ${ }^{9}$

A nemzetközi szakirodalomban csak elvétve található olyan - validált eszközzel végzett adatfelvétel (pl. táplálkozási napló, élelmiszer-fogyasztási gyakoriság kérdőív) alapján készült - tanulmány, amely 15-18 éves fiatalok komplex táplálkozás-egészségügyi állapotának vizsgálati eredményeit ismerteti. ${ }^{10}$ A kizárólag önkitöltős kérdőíves eszközzel történt adatgyűjtésből származó adatok ugyanis nem tekinthetők a táplálkozási vizsgálatok esetében hitelesnek. ${ }^{11}$

Célul tűztem ki a középiskolások körében a reggelizés mint táplálkozási szokás rendszeresebbé tételére irányuló törekvés eredményességének mérését, ennek érdekében a táplálkozási szokások nyomon követését, továbbá az általam vezetett beavatkozás hatékonyságának megállapítását.

\section{MÓDSZERTAN}

A bonyolult, soktényezős pedagógiai jelenségek világában gyakori kívánalom, hogy tudományos igénnyel vizsgáljunk meg egy általunk hasznosnak tartott vagy/és vélt beavatkozás (intervenció) hatásait. Természetes és alapvető törekvés, hogy a tervezett és a terv szerint kivitelezett pedagógiai kutatás változást idézzen elő egy vagy több tényezőnél. ${ }^{12} \mathrm{~A}$ beavatkozás - mely egyszerre volt oktatásinevelési tevékenység és kutatási módszer - során a táplálkozási szokások tényezőit szerettem volna befolyásolni a foglalkozások ismeretén keresztül. Kontrollcsoport helyett a két, különböző oktatási folyamatban részt vevő diákok eredményeit hasonlítottam össze, ahol a pedagógusnak nem volt nagy szerepe az egyes osztályoknál, tekintettel arra, hogy ugyanaz a pedagógus múködött közre - Lucia Mason és Luisa Scrivani kutatásához hasonlóan. ${ }^{13}$

A kutatást négy különböző középfokú intézménytípusban végeztem. A középiskolások egészséges táplálkozásra nevelése és az azt kísérő kutatómunka bemutatkozással, a célok ismertetésével és a használni tervezett kérdőívek kipróbálásával kezdődött. $A z$ ismertetést szolgáló szülői értekezleteket és a nyilatkozattételeket a - tapasztalatok alapján - módosított kérdőívek és - kvantitatív és kvalitatív jellemzők megállapítását lehetővé tévő validált - hétnapos táplálkozási napló kitöltése követte. Ezután tíz-tíz alkalommal interaktív tanóra keretében vettek részt a középiskolások az egészséges táplálkozással kapcsolatos foglalkozáson. Az adatfelvétel táplálkozási kérdőív és a táplálkozási napló párhuzamos kitöltésén, az értékelés az elemzéseken túl azok összevetésén is alapult. Az „A" oktatási folyamat résztvevőinek a második $1 \times 5$ órás foglalkozására egy év elteltével került sor: az első félévben elhangzott témaköröket (az egyes témakörök információanyagának első egységét) fél év szünet követte, majd a következő tanév hasonló időszakában ugyanazok a témakörök ismétlődtek - eltérő tartalommal. A „B” oktatási folyamat szerint az öt téma feldolgozására két-két hónap, szintén havonta egy találkozás állt rendelkezésre. A középiskolások megközelítőleg fele-fele arányban vettek részt az "A" és a „B” oktatási folyamatban (49\%, illetve 51\%). A kutatás ütemezését az 1. ábra mutatja. 
1. ábra: A kutatás ütemezése

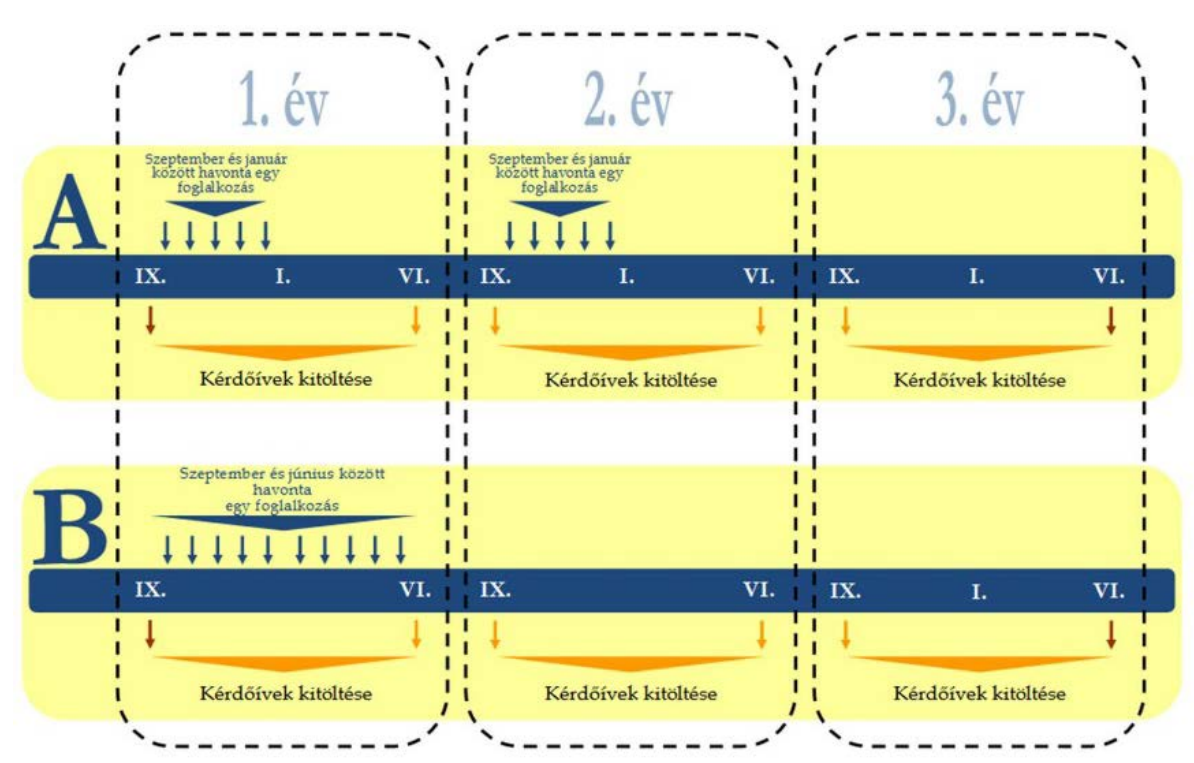

Forrás: Szerző saját ábrája

A foglalkozásokon a vizsgálatban részt vevő diákok (teljes) osztályai részt vehettek, a vizsgálatba azonban csak egészséges, ismert táplálékallergiában nem szenvedő, önkéntes részvételű 9 . és 10. évfolyamos (14,5-16,5 éves) tanulókat vontam be, a négy intézménytípusból, a nem szerint is törekedve az azonos gyakorisági eloszlásra.

A 400 középiskolás közremúködésével tervezett, nem reprezentatív, egyetlen lépésben végrehajtott csoportos mintavételű vizsgálatban a tanulók önkéntesen vettek részt. Részvételüket - következmények nélkül-bármikor megszakíthatták, azonban ez nem volt jellemző (2 tanuló, <1\%). További 27 tanuló (7\%) lemorzsolódásának objektív okai voltak: iskolai lemorzsolódás, időközben diagnosztizált táplálkozással összefüggő - betegségek, várandósság. Az egyszerű véletlen mintavétel alkalmazásával a részt vevő intézmények torzító hatása nem volt kiküszöbölhető.

Az eredmények 364 középiskolás (181 fiú /50\%/ és 183 lány /50\%/) részvételén alapulnak.

Az elektronikus feldolgozás IBM-kompatibilis személyi számítógépen történt Microsoft Excel és SPSS 22.0 statisztikai programcsomag segítségével. Az adatok elemzéséhez meghatároztam az egyes csoportok (alminták) gyakoriságát, átlagait, szórásait, minimum- és maximumértékeit, valamint az utób- biak alapján variációterjedelmüket. Az adatelemzést a 95\%-os konfidencia-intervallumok összehasonlításával, kétmintás t-próbával, a nominális változók összefüggés-vizsgálatát khi-négyzet-próbával végeztem el. A paramétereket nemcsak a teljes populációra, hanem nemenkénti bontásban (fiúk és lányok), valamint az „A" és „B" oktatási folyamatban részt vevők szerinti almintákban is vizsgáltam.

\section{EREDMÉNYEK}

A kérdőívben a "Miért fontos a rendszeres reggelizés?" kérdésre nyolc - négy igaz és négy hamis - állításból választhattak ki többet is a diákok. Tekintettel a reggeli fontosságára ebben a korosztályban (is), kizárólag a négy helyes és négy hibás válasz együttes eltalálását fogadtam el hibátlannak. A kapott eredményekből a kutatás elején (a foglalkozásokat megelőzően) is kiderült, hogy a középiskolások jól tájékozottak a reggelizés fontosságáról, ismereteik széles körüek. 155 fiú (86\%) és 156 lány (85\%), összesen 311 diák (85\%) mind a nyolc állítást helyesen válaszolta meg. $A z$ „ $A$ ” és a „B" oktatási folyamatban résztvevők helyes/hibás válaszainak gyakorisága között nem volt különbség ( $p>0,05)$. [2. ábra] (A diagramokon negatív irány jelöli a tévesen igaznak vélt hamis állítást.) 
2. ábra: A reggelivel kapcsolatos állitások gyakorisága a kutatás elején az "A" és a " $B$ ” oktatási folyamatban (igaz: 2., 5., 7. és 8. állítás; hamis: 1., 3., 4. és 6. állitás)

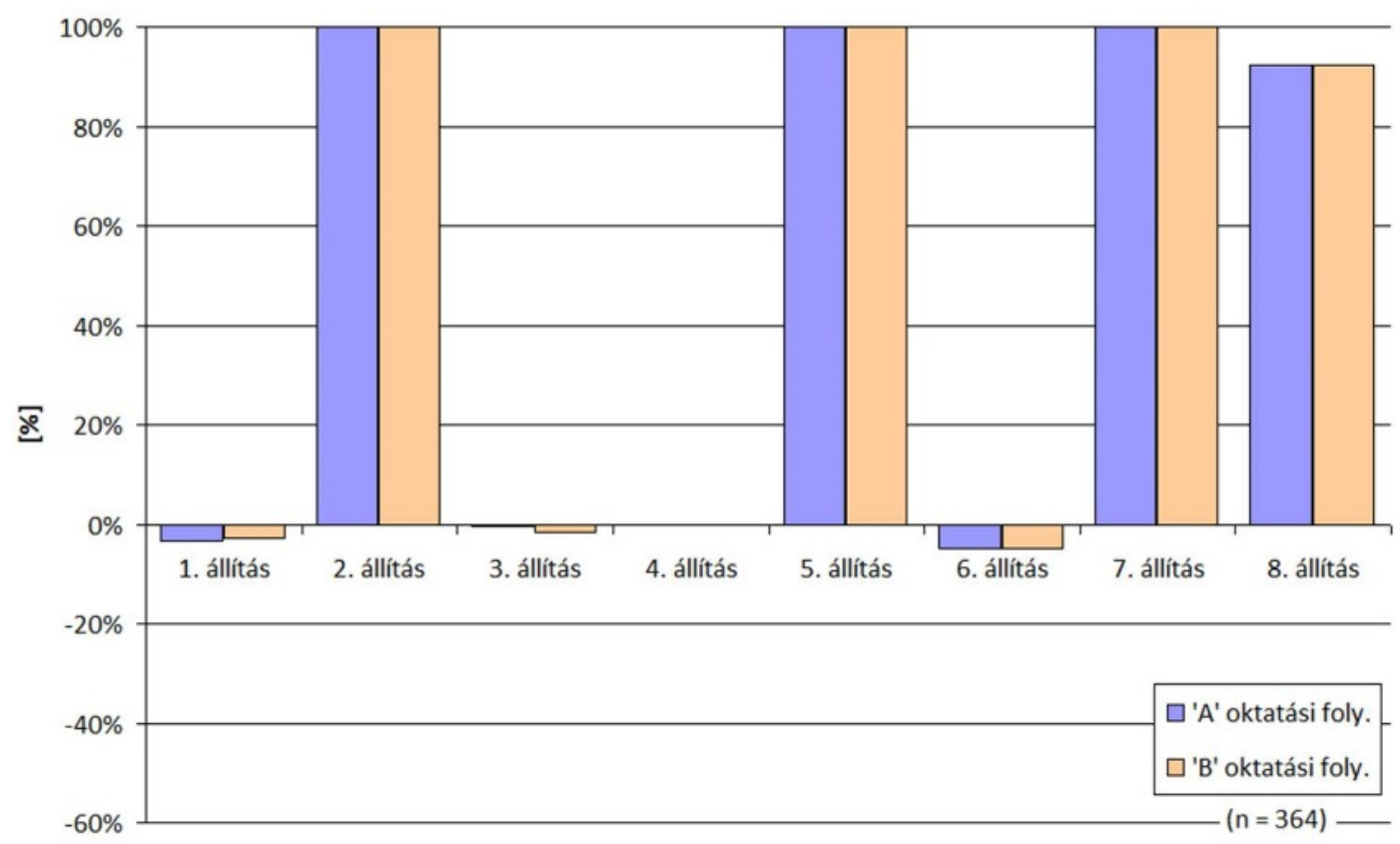

Forrás: Szerző saját ábrája

Ábramagyarázat: A 4. hamis állítást minden megkérdezett diák helyesen tudta. A hamis állításokat (1., 3. és 6 . állítás) hibásan tudók negatív előjellel szerepelnek az ábrán.

Mind a négy igaz állítást felismerte a diákok 92\%-a, a fiúk $92 \%$-a és a lányok 91\%-a. Kivétel nélkül a négy hamis állítást a diákok szintén 92\%-a (a fiúk és a lányok $92-92 \%-a)$ ismerte fel. A diákok a négy helyes állításból legalább hármat, míg a hibás állításokból legfeljebb kettőt tévesztettek. Az összes diák átlagát tekintve a helyes állításokkal elért eredmény 3,9 ( \pm SD-érték 0,3 ), a hibás állítások átlaga $0,1 \pm 0,4$ volt.

Az első, valamint a második év végén kitöltött kérdőívek alapján a diákok eredménye kismértékben javult, mely - az első év végétől - közelebb állt a harmadik év végi eredményhez, mint a foglalkozásokat megelőzőhöz. A hibás válaszok belső dinamikájából azt az óvatos megállapítást tehetjük, hogy az ilyen jellegú kérdésfeltevéssel (egy kérdésfeltevés kapcsán annak eldöntése, hogy több állítás igaz vagy hamis) kapott nagyobb hibalehetőség oka lehet a felületesség, kapkodás, „lezserség”.

A kutatás végén (3. év végén) minden fiú és minden lány, összességében minden diák (100\%) tisztában volt azzal, hogy a rendszeres reggelizés fontos, mert ellátja a testet a délelőtti fizikai és szellemi tevékenységekhez szükséges energiával, hozzájárul az egészséges testtömeg fenntartásához, segíti az agyi múködést és a gondolkodást, valamint javítja a memóriát és fokozza a koncentrálóképességet. $A z$ " $A$ ” és a „B" oktatási folyamatban résztvevők helyes/hibás válaszainak gyakorisága között ekkor szintén nem volt különbség $(p>0,05)$. [3. ábra]

A négy hamis állításnál az elért átlagos összesített eredmény szerint a fiúk 99\%-a, a lányok 98\%-a (a diákok 99\%-a) adott helyes választ. Két hibás állítást (a rendszeres reggelizés gátolja az agyi múködést és a gondolkodást, illetve egész napos fizikai és szellemi tevékenységekhez szükséges energiával lát el) a diákok 100\%-a helyesen ismerte fel. Három lány tévesen - úgy vélte, hogy a rendszeres reggelizés hozzájárul a túlsúly kialakulásához (az energiaegyensúly fenntartásához járul hozzá, bár az is igaz, hogy nagymértékű energiabevitel esetén valóban túlsúlyt/elhízást okozhat, azonban a rendszeresség ez ellen hat), továbbá egy fiú vélte a foglalkozásokat követően is úgy, hogy a rendszeres reggelizés azért fontos, mert nagy cukortartalmú ételeket tartalmaz. 
3. ábra: A reggelivel kapcsolatos állitások gyakorisága a kutatás végén az "A" és a "B" oktatási folyamatban (igaz: 2., 5., 7. és 8. állítás; hamis: 1., 3., 4. és 6. állitás)

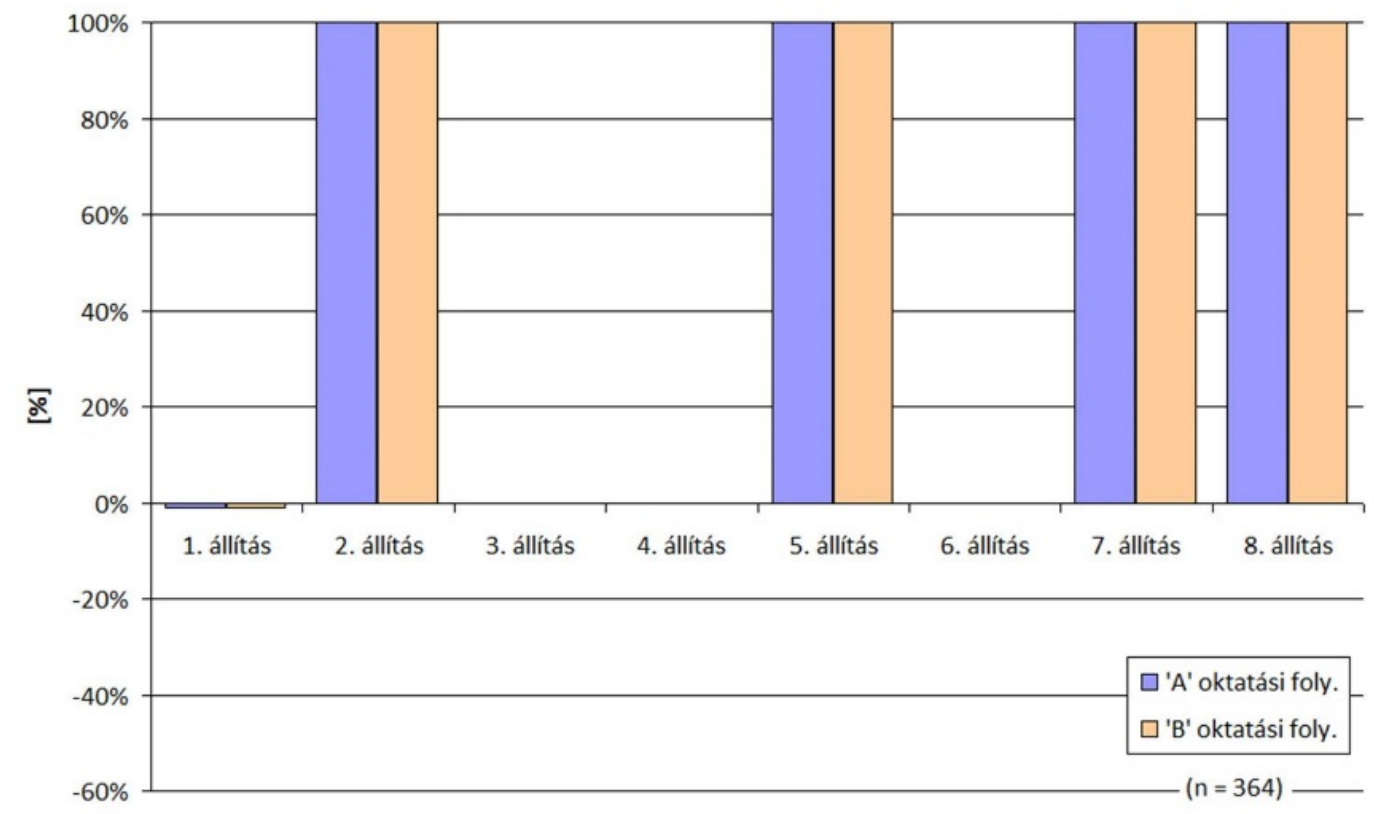

Forrás: Szerző saját ábrája

Ábramagyarázat: A 3., 4. és 6. hamis állítást minden megkérdezett diák helyesen tudta. A hamis állítást hibásan tudók negatív előjellel szerepelnek az ábrán.

A foglalkozásokat megelőzően és a 3. év végén, a reggelivel kapcsolatos nyolc hibátlan állítással elért eredményt összehasonlítva megállapítható, hogy a korábbi, nem teljesen hibátlan választ adó 53 tanuló közül 49 (14\%) ért el hibátlan eredményt. [1. táblázat] Az eloszlások közötti különbség nem véletlen, a változást bizonyítja a szignifikáns kapcsolat $\left(x^{2}=23,732, p<0,05\right)$.

1. táblázat: A reggelivel kapcsolatos nyolc hibátlan állitás ismeretének kereszttáblája a kutatás elején és a végén

\begin{tabular}{|c|c|c|c|}
\hline \multirow[t]{2}{*}{$(n=364)$} & & \multicolumn{2}{|c|}{ Kutatás elején } \\
\hline & & $\begin{array}{c}\text { Hibás } \\
53(15 \%)\end{array}$ & $\begin{array}{c}\text { Helyes } \\
311(85 \%) \\
\end{array}$ \\
\hline \multirow{2}{*}{ Kutatás végén } & $\begin{array}{l}\text { Hibás } \\
4(1 \%) \\
\end{array}$ & $\begin{array}{c}4 \\
(1 \%) \\
\end{array}$ & $\begin{array}{c}0 \\
(0 \%) \\
\end{array}$ \\
\hline & $\begin{array}{l}\text { Hibátlan } \\
360 \text { (99\%) }\end{array}$ & $\begin{array}{c}49 \\
(14 \%)\end{array}$ & $\begin{array}{c}311 \\
(85 \%)\end{array}$ \\
\hline
\end{tabular}

$\chi^{2}=23,732$. Az eredmény szignifikáns, $p<0,05$.

Forrás: Szerző saját táblázata

$\mathrm{Az}$ „A" oktatási folyamatban részt vevők közül öttel több tanuló értékelhető eredményesebbnek tudása tekintetében a „B" oktatási folyamatban résztvevőkhöz képest, azonban ha a korábban hibás választ adókhoz viszonyítjuk (27/29, illetve 22/24), akkor ez a különbség eltűnik (93\% vs. 92\%). [2. táblázat]
A középiskolások táplálkozási szokásainak felméréséhez a táplálkozási naplók - mint dokumentumok - elemzésének eredményeit használtam fel. Rendszeresen reggelizik a diák, ha a hét minden napján fogyaszt reggelit. 
2. táblázat: A reggelivel kapcsolatos hibátlan állitások ismerete változásának összehasonlitása a két oktatás folyamatban részt vevőknél

\begin{tabular}{|c|c|c|c|c|}
\hline \multicolumn{2}{|c|}{ Állításegyüttes (8 állítás) } & Tanulók & \multicolumn{2}{c|}{ Értékelés } \\
\hline Kutatás elején & Kutatás végén & {$[\mathrm{n}]$} & $\begin{array}{c}\text { 'A' oktatási fo- } \\
\text { lyamat }\end{array}$ & $\begin{array}{c}\text { 'B' oktatási fo- } \\
\text { lyamat }\end{array}$ \\
\hline \hline Hibás & Hibás & 4 & 2 & 2 \\
\hline Hibás & Hibátlan & 49 & $27+$ & $22+$ \\
\hline Hibátlan & Hibás & 0 & & 160 \\
\hline Hibátlan & Hibátlan & 311 & 151 & $22+$ \\
\hline
\end{tabular}

$\chi^{2}=0,0005$. Az eredmény nem szignifikáns, $p>0,05$.

Forrás: Szerző saját táblázat

A kutatás elején a vizsgálatban részt vevő diákok 48\%-a reggelizett rendszeresen: a fiúk között ez gyakoribb volt (52\%), mint a lányok körében (44\%). $A$ két oktatási folyamatban („A $A$ ”́s a „B”) résztvevők rendszeres reggelizési gyakoriságában nem volt különbség (49 vs. 47\%).

Ami azt a pozitív változást illeti, hogy a tanulók rendszeresen reggeliznek, a legjobb eredményt a 2. év végére érték el. Ekkor a diákok 72\%-a reggelizett rendszeresen, a fiúk továbbra is nagyobb arányban, mint a lányok (76 vs. 68\%). A harmadik év végére mind a fiúk, mind a lányok körében csökkent a rendszeresen reggelizők aránya. Ekkor a diákok 59\%-a (a fiúk 64\%-a és a lányok 55\%-a) reggelizett rendszeresen: a korábban reggelit nem rendszeresen fogyasztó diákok 21\%-a vált rendszeres reggelizővé.

4. ábra: „A" és a „B" oktatási folyamatban a rendszeres reggelizők arányának változása a három év során

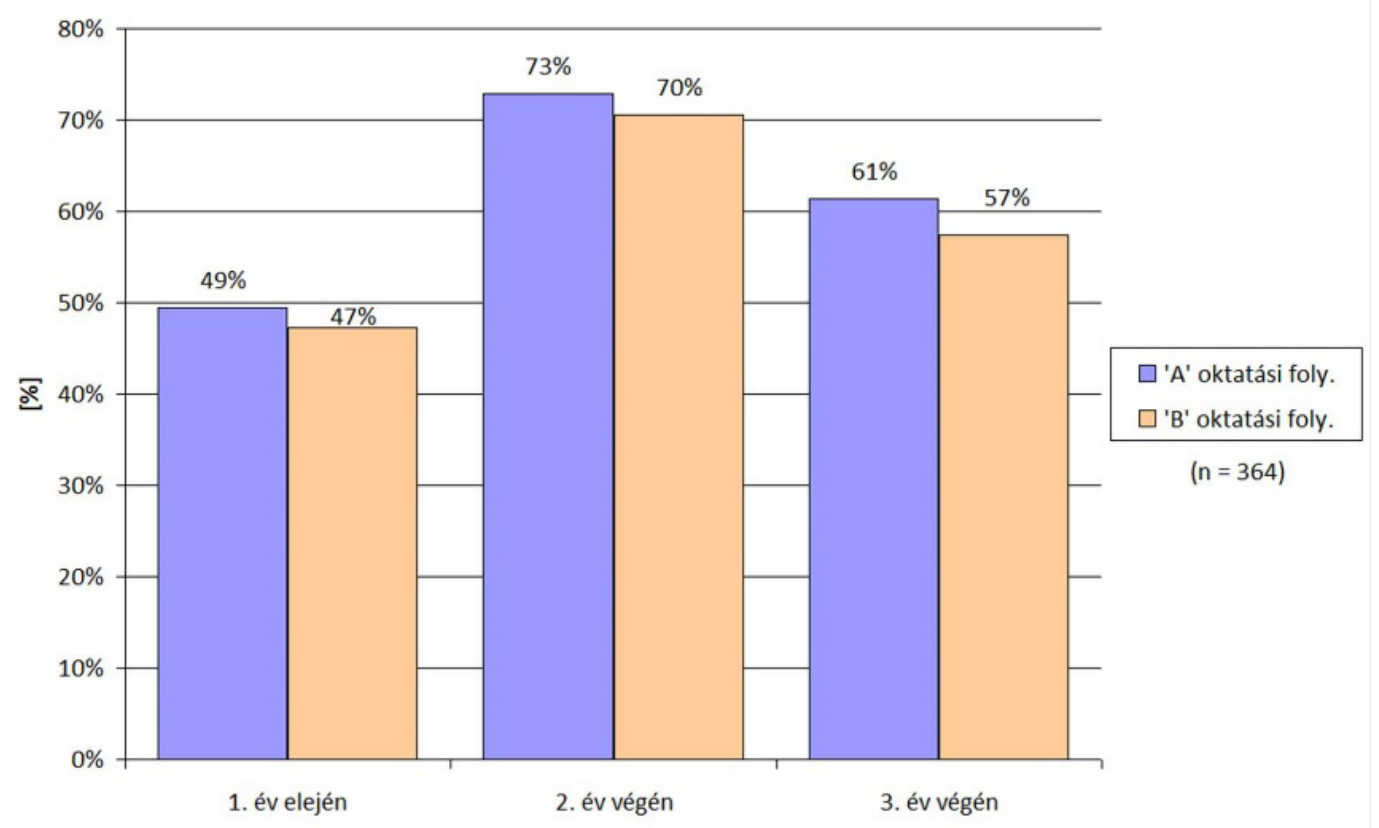

Forrás: Szerző saját táblázat 
$A z$ „A" és a „B” oktatási folyamatban résztvevők közül a rendszeres reggelizők arányának változását szemlélteti a 4. ábra. $\mathrm{Az}$ "A" oktatási folyamatban minden naplókitöltéskor nagyobb arányban voltak a rendszeresen reggeliző diákok (az 1. év elején természetesen a random választás miatt ennek nincs jelentősége), részben ez a különbség maradt meg az évek során, illetve elmondható, hogy míg az „A $\mathrm{A}^{\prime}$ oktatási folyamatban 22 tanuló szokott „vissza” a nem reggelizésre, addig a „B" oktatási folyamatban 25 . A különbség egyik esetben sem szignifikáns. Megemlítendo, hogy mind az „A", mind a „B" oktatási folyamatban egy-egy diák volt, aki a harmadik év végére vált rendszeres reggelizővé. További pozitívumként elmondható, hogy nem volt olyan diák, aki a három év alatt „leszokott” volna a rendszeres reggeliről. Az „A" oktatási folyamatban 47 tanulót (26\%), a „B” oktatási folyamatban 54 tanulót (30\%) nem sikerült olyan mértékben eredményesen megszólítani, hogy rendszeresen reggelizzen. (Ez a két arány szintén nem különbözik egymástól.)

Annak megállapításához, hogy az elsajátított ismeretanyag (tudás) milyen mértékben épült be a magatartásba (táplálkozási szokások), a rendszeres reggelizés fontosságát, mint ismeretkérdést a rendszeres reggelizéssel, mint szokással hasonlítottam össze. A kereszttáblák minden összehasonlításnál négy csoportot eredményeznek:

- a hibás ismeret és a rossz szokás eredményezte, hogy nem jól tudta, és nem is (úgy) tett,

- a helyes ismeret ellenére a rossz szokás eredményezte, hogy jól tudta, de nem (úgy) tett,

- a hibás ismerettől „függetlenül” a jó szokás eredményezte, hogy nem jól tudta, mégis jól tett(e),

- a helyes ismeret mellett a jó szokás eredményezte, hogy jól tudta, és jól is tett(e), ez utóbbi eredményezi a tudatos táplálkozást (ez esetben a rendszeres reggelizésre vonatkozóan).

Sem a kutatás elején, sem annak végén nem volt szignifikáns kapcsolat a rendszeres reggelizés fontosságának ismerete és a rendszeres reggelizés szokása között. [3. és 4. táblázat] $A z$ „A" oktatási folyamatban résztvevők eredményesebbnek bizonyultak a „B” oktatási folyamatban résztvevóknél (61\% vs. $56 \%)$, de csak olyan kis mértékben, hogy az statisztikailag nem kimutatható. [5. és 6. táblázat]

3. táblázat: A rendszeres reggelizés fontossága és a táplálkozási napló szerinti szokás kereszttáblája a kutatás elején

\begin{tabular}{|c|c|c|c|}
\hline \multicolumn{2}{|c|}{$(n=364)$} & \multicolumn{2}{|c|}{ Ismeret } \\
\hline \multirow{2}{*}{ Szokás } & $\begin{array}{c}\text { Rossz szokás } \\
188(52 \%)\end{array}$ & $\begin{array}{c}30 \\
(9 \%) \\
\end{array}$ & $\begin{array}{c}158 \\
(43 \%) \\
\end{array}$ \\
\hline & $\begin{array}{l}\text { Jó szokás } \\
176(48 \%)\end{array}$ & $\begin{array}{c}23 \\
(6 \%)\end{array}$ & $\begin{array}{c}153 \\
(42 \%)\end{array}$ \\
\hline
\end{tabular}

$\chi^{2}=0,6100$. Az eredmény nem szignifikáns, $p>0,05$.

Forrás: Szerző saját táblázata

4. táblázat: A rendszeres reggelizés fontossága és a táplálkozási napló szerinti szokás kereszttáblája a kutatás végén

\begin{tabular}{|c|c|c|c|}
\hline \multirow[t]{2}{*}{$(n=364)$} & & \multicolumn{2}{|c|}{ Ismeret } \\
\hline & & $\begin{array}{l}\text { Hibás } \\
4(1 \%)\end{array}$ & $\begin{array}{c}\text { Helyes } \\
360(99 \%)\end{array}$ \\
\hline \multirow{2}{*}{ Szokás } & $\begin{array}{c}\text { Rossz szokás } \\
148(41 \%)\end{array}$ & $\begin{array}{c}0 \\
(0 \%)\end{array}$ & $\begin{array}{c}148 \\
(41 \%)\end{array}$ \\
\hline & $\begin{array}{l}\text { Jó szokás } \\
216 \text { (59\%) }\end{array}$ & $\begin{array}{c}4 \\
(1 \%)\end{array}$ & $\begin{array}{c}212 \\
(58 \%)\end{array}$ \\
\hline
\end{tabular}

$\chi^{2}=2,7712$. Az eredmény nem szignifikáns, $p>0,05$.

Forrás: Szerző saját táblázata 
5. táblázat: A rendszeres reggelizés fontossága és a táplálkozási napló szerinti szokás kereszttáblája a kutatás végén $a z$ "A" oktatási folyamatban

\begin{tabular}{|l|c|c|c|}
\cline { 3 - 3 } \multicolumn{2}{c|}{} & \multicolumn{2}{c|}{ Ismeret } \\
\cline { 3 - 4 } \multicolumn{2}{c|}{} & $\begin{array}{c}\text { Hibás } \\
2(1 \%)\end{array}$ & $\begin{array}{c}\text { Helyes } \\
178(99 \%)\end{array}$ \\
\hline \multirow{4}{*}{ Szokás } & Rossz szokás & 0 & 69 \\
& $69(38 \%)$ & $(0 \%)$ & $(38 \%)$ \\
\cline { 2 - 4 } & Jó szokás & 2 & 109 \\
& $111(62 \%)$ & $(1 \%)$ & $(61 \%)$ \\
\hline
\end{tabular}

$\chi^{2}=1,2572$. Az eredmény nem szignifikáns, $p>0,05$.

Forrás: Szerző saját táblázata

6. táblázat: A táplálkozási ritmus ismeretének és a táplálkozási napló szerint követett kereszttáblája a kutatás végén $a z$ „A" oktatási folyamatban

\begin{tabular}{|c|c|c|c|}
\hline \multirow[t]{2}{*}{$(n=184$} & & \multicolumn{2}{|c|}{ Ismeret } \\
\hline & & $\begin{array}{l}\text { Hibás } \\
2(1 \%)\end{array}$ & $\begin{array}{c}\text { Helyes } \\
182(99 \%)\end{array}$ \\
\hline \multirow{2}{*}{ Szokás } & $\begin{array}{c}\text { Rossz szokás } \\
79(43 \%)\end{array}$ & $\begin{array}{c}0 \\
(0 \%) \\
\end{array}$ & $\begin{array}{c}79 \\
(43 \%) \\
\end{array}$ \\
\hline & $\begin{array}{c}\text { Jó szokás } \\
105(57 \%) \\
\end{array}$ & $\begin{array}{c}2 \\
(1 \%) \\
\end{array}$ & $\begin{array}{c}103 \\
(56 \%)\end{array}$ \\
\hline
\end{tabular}

$\chi^{2}=1,5213$. Az eredmény nem szignifikáns, $p>0,05$.

Forrás: Szerző saját táblázata

\section{KÖVETKEZTETÉSEK}

Az ismeretkérdésre adott válasz alapján megállapítható, hogy a foglalkozásokat megelőzően (is) jól tájékozott volt a középiskolás korosztály: a reggeli jelentőségének a diákok 85\%-a volt tudatában. A kutatás végén a tanulók közül szinte mindenki tisztában volt a rendszeres reggelizés fontosságával (99\%).

A rendszeres, egészséges táplálkozás témájú foglalkozások annak ellenére, hogy sem az összes diákra vonatkozóan (teljes minta), sem az oktatási folyamat szerinti diákcsoportokban (alminták) nem voltak képesek a szokásrendszerben átfogó változásokat indukálni, vannak részeredmények, amelyek pozitívak. Ilyen az a tény, hogy a foglalkozásokat megelőzően rendszeresen nem reggeliző (nem rendszeresen reggeliző) diákok 21\%-a vált rendszeres reggelizővé.

A kutatásomban vizsgált kétféle ütemezés összehasonlítása nem eredményezett statisztikailag mérhető különbségeket: a lexikális tudás bővülését te- kintve egyaránt eredményesnek bizonyultak, ezzel szemben a várt (remélt) szokásváltozások esetében az eredmények mindkét ütemezésben elmaradtak a részt vevő tanulóknál. Feltehetően egy szükséges ismeretanyagot átölelő és megfelelő intenzitású, bármilyen gyakoriságú foglalkozássorozattal érdemes a középiskolások felé fordulni az egészséges táplálkozás témakörében. A diákok befogadóak voltak, az ismereteik bővültek, a szokásaikat érintően pedig idővel - remélhetôleg - megteszik a szükséges változtatásokat.

A diákok egészséges táplálkozásra nevelése során nagyon fontos behatárolni azt az információtartalmat, ami szükséges és elégséges az egészséges táplálkozáshoz. A rendszeres reggelizés fontossága egyértelmúen ilyen ismeret. Ráadásul a reggeli nem egy elvont fogalom (míg például az energiaegyensúly és a kalória nem kézzelfogható), hanem egy/több élelmiszer konkrét elfogyasztása, így számos lehetősége van az egészséges táplálkozásra nevelő szakembernek az illusztrálásra, példamutatásra, szituációs gyakorlatokra, játékos elemekkel és érzelmi ráhatással támogatott oktatási módszerek- 
re, a tanultak tapasztalatokkal és gyakorlattal való megtámogatására annak érdekében, hogy az ismeret gyakorlattá váljon.

A szokások kialakítása, és a szokások megváltoztatása nem tekinthető azonos nevelési feladatnak. A szokások kialakítása példaadással, gyakoroltatással, következetességgel, követeléssel kisgyermekkorban kezdődik, az, hogy azok "jók” avagy "helytelenek/rosszak", az elsősorban a családban gyakorolt magatartások, tevékenységek és értékrend függvénye. A rögzült szokások megváltoztatása nehezebb, hosszabb időt igénylő feladat. Ebbe a folyamatba kapcsolódik be az óvoda, az iskola, (a média), amikor a jó/helyes/értékes szokásokkal megismerteti a felnövekvőket, az ehhez szükséges ismereteket megtanítja, és igyekszik a megfelelő tevékenységek, magatartásformák gyakoroltatásával, a szükséges fel- tételek megteremtésével elérni - jelen esetben - a helyes/egészséges táplálkozási szokások kialakítását. Ennek az életvitelbe, tevékenységekbe, magatartásba való beépülése attól is függ, hogy mennyire érték az egészség. Az iskolai nevelésben kiemelt fejlesztési terület - a minden múveltségi területbe beépülő - a testi és lelki egészségre nevelés, és ennek keretében az egészséges táplálkozási szokások kialakítása.

\section{KÖSZÖNETNYILVÁNITTÁS}

Ezúton is hálásan köszönöm témavezetőmnek, dr. Nádasi Mária professzor asszonynak, hogy tanítványai közé fogadott, valamint, hogy doktori tanulmányaim és kutatómunkám során mindvégig élvezhettem önzetlen támogatását.

\footnotetext{
${ }^{1}$ Megson M, Wing R, Leahey TM. Effects of breakfast eating and eating frequency on body mass index and weight loss outcomes in adults enrolled in an obesity treatment program. J Behav Med 2017;Jan 21. doi: 10.1007/s10865-0179828-0.

${ }^{2}$ Locke J. Gondolatok a nevelésről. Katholikus Középiskolai Tanáregyesület, Budapest, 1914. Másodközlés. In Platóntól Steinerig. Egyetemes neveléstörténeti szöveggyűjtemény, Balázs S. (eds.) Eszterházy Károly Tanárképző Főiskola, Eger, 1999. pp 152-187.

${ }^{3}$ Fináczy E. Az újkori nevelés története (1600-1800). Vezérfonal egyetemi előadásokhoz. Királyi Magyar Egyetemi Nyomda, Budapest, 1927.

${ }^{4}$ Aszmann A. Magyar diákok egészségi állapota és az iskola. In Nevelési kézikönyv nem csak osztályfőnököknek, Szekszárdi J. (eds.) OKI - Dinasztia, Budapest, 2001. pp 49-71.

${ }^{5}$ Antal M, Nagy K, Biró L et. Hazai reprezentatív felmérés a középiskolás fiatalok táplálkozási és életmódbeli szokásairól. Orv Hetilap 2003;144(33):1631-6.

${ }^{6}$ Greiner E. Táplálkozási szokások - a reprezentatív táplálkozás-egészségügyi szűrővizsgálat eredményeinek értékelése. Pediáter 2001;10(3): 176-7.

${ }^{7}$ Németh Á. Serdülőkorúak táplálkozási szokásai, testképe és szubjektív jólléte. Új Diéta 2007;14(3-4):2-4.

${ }^{8}$ Németh Á. Táplálkozási szokások és fogápolás. In Serdülőkorú fiatalok egészsége és életmódja, Németh Á. (eds.) OGYEI, Budapest, 2007. pp. 60-66.

${ }^{9}$ Németh Á. Táplálkozási szokások és fogápolás. In Egészség és egészségmagatartás iskoláskorban. Az Iskoláskorú gyermekek egészségmagatartása elnevezésű, az Egészségügyi Világszervezettel együttmúködésben megvalósuló nemzetközi kutatás 2014. évi felméréséről készült nemzeti jelentés, Németh Á, Költő A. (eds.). NEFI, Budapest, 2016.

${ }^{10}$ Antal M.: Táplálkozás-egészségügyi szűrővizsgálatok az irodalom tükrében - a reprezentatív szűrővizsgálat előkészítése, szervezése. Pediáter 2001;10(3):175-6.

${ }^{11}$ Lelovics Zs. Táplálkozási és tápláltsági állapotot vizsgáló módszerek. KE - PE - SZGI, Kaposvár - Veszprém - Szeged, 2015.

${ }^{12}$ Csíkos Cs. Pedagógiai kísérletek kutatásmódszertana. Gondolat, Budapest, 2012.

${ }^{13}$ Mason L, Scrivani L. Enhancing Students' Mathematical Beliefs: an intervention study. Learning and Instruction 2004;14(2):153-76.
} 